\title{
The Relationship between Depression and Severe Obesity: A Case-Control Study
}

\author{
Marja Koski ${ }^{*}$, Hannu Naukkarinen ${ }^{2,3}$ \\ ${ }^{1}$ Department of Psychiatry, University of Helsinki, Helsinki, Finland \\ ${ }^{2}$ University of Helsinki, Helsinki, Finland \\ ${ }^{3}$ Carea Hospital District, Kymenlaakso Psychiatric Hospital, Kuusankoski, Finland \\ Email: *marja.koski@helsinki.fi, *marja.koski@pp.fimnet.fi
}

How to cite this paper: Koski, M. and Naukkarinen, H. (2017) The Relationship between Depression and Severe Obesity: A Case-Control Study. Open Journal of Psychiatry, 7, 276-293.

https://doi.org/10.4236/ojpsych.2017.74024

Received: June 20, 2017

Accepted: August 14, 2017

Published: August 17, 2017

Copyright ( $) 2017$ by authors and Scientific Research Publishing Inc. This work is licensed under the Creative Commons Attribution International License (CC BY 4.0).

http://creativecommons.org/licenses/by/4.0/

(c) (i) Open Access

\begin{abstract}
Objectives: This study investigated the relationship between depression and obesity in severely obese retired individuals using the case-control method. Methods: The subject group consisted of 112 individuals receiving a permanent disability pension primarily due to obesity. The prevalence of depression was measured with a personal psychiatric interview and the Beck Depression Inventory (21). Male and female controls were selected separately, with five controls for male subjects and three controls for female subjects. The controls were matched with the subjects according to place of residence, age, time that pension was granted, and occupation. The statistical analyses included $\chi^{2}$ tests, means, $t$-tests for paired variables, a conditional logistic linear model, correlation coefficients and the percent distributions. Results: Depression was diagnosed more often in the subject group than in the control group according to the psychiatric interview. Based on the conditional logistic linear model, individuals with severe obesity had a higher risk of depression than those in the control group. The most common disturbance was chronic depression in both groups. Additionally, there were significant findings regarding the outcome of depression for every classification in the psychiatric interview. According to the Beck Depression Inventory, depression was more common in subjects than in controls. However, slight depression was most common in the study group. Seven percent of the subjects had masked depression. The questions on the Beck Depression Inventory that measure irritability, indecisiveness, body image and ability to work were nearly significant. Regarding weight changes, the Beck Depression Inventory questions on both weight loss $(p=0.014)$ and weight gain $(p=0.017)$ were statistically significant. In the study group, individuals with BMI over $40 \mathrm{~kg} / \mathrm{m}^{2}$ gained the most weight; however, weight loss was very low overall. Regarding changes in appetite, the majority of the study group responded that they had a poorer appetite than previously. Conclusion:
\end{abstract}


This research is essential and provides information on groups that have not been previously examined. The findings from this study can be utilized to improve the care and understanding of individuals with severe obesity.

\section{Keywords}

Severe Obesity, Depression, Beck Inventory, Body Mass Index, Weight in Depression

\section{Introduction}

Obesity is a multifaceted illness on the biological basis which includes genetic and biological components that are involved in normal body growth, eating habits, energy expenditure, and adipose tissue function [1]. The level of obesity in Finland has been an increasing problem in Finland as well as worldwide [2].

Zhang et al. [3] researched the pathophysiology of obesity as well as interventions targeting it. They focused on not only the factors influencing the development of obesity but also the role of hormones and intestinal peptides. They also conducted neuroimaging studies, and their findings provide insight into the portion of the brain involved in the development of obesity. In their studies, brain circuits were considered to be related to obesity. Unhealthy eating has also provided a new perspective on obesity, and information on food addiction has recently been updated. According to Milaneschi et al. [4], leptin levels are higher in men, especially men with abdominal obesity. This finding supports the fact that there is some type of biological link between depression and obesity that also leads to negative health outcomes.

According to Chen et al. [5], the prevalence of depression is higher in adulthood among women. Depression is found more often in individuals with abnormal body weight. In particular, younger obese women have a higher risk of depression. Mauri et al. [6] found in their research on morbid obesity that mood disorders were the most common diagnoses in obese individuals. Obesity has been significantly associated with mood disorders but not anxiety disorders [7]. Obesity is associated with anxiety, depression and fewer feelings of well-being in female individuals [8]. After gastric bypass, patients who had an Axis I disorder, especially a mood or anxiety disorder exhibited poorer weight outcomes at 6 months [9].

Obesity can also be understood as an indirect form of self-destruction. Typical forms of indirect self-destructive behavior (ISDB) include excessive smoking, alcohol and drug abuse, excessive self-induced stress and strain, and difficulty accepting the restrictions imposed by long-term illnesses [10]. ISDB usually lasts for years, and the individual is not aware of his/her behavior, especially its suicidal nature [10]. In some cases, ISDB appears to protect the individual from underlying depression or anxiety. Occasionally, the individual acts very impulsively 
without thinking of the long-term consequences of his/her behavior [11].

Ma and Xiao [12] examined a population-based sample of people from the US. The degree of obesity is an independent risk factor for depression in women in obesity class 3 . The risk for depression is homogeneous within the obese population. According to Zimmerman [13], several symptoms are associated with obesity, and these symptoms are the same as those of major depressive disorder (MDD). In their study, increased appetite, increased weight and tiredness were lower in obese patients than in the non-obese population. Faulconbridge et al. [14] discovered that due to fears of a mood disorder, depressive individuals are excluded more often from weight loss trials. Similarly, depressive participants most likely will not lose weight to a satisfactory degree. Weight loss is not associated with incident symptoms in depression but instead can prevent these symptoms. Fowler-Brown et al. [15] assumed that obesity is not associated with risk for depression in the general population, although it is associated with an increased risk of having depressive problems in higher social classes; therefore, sociodemographic characteristics are important when determining the association between depression and obesity. According to Wild et al. [16], the appearance of symptoms in obesity and depression varies widely between BMI classes. They believed that women with BMIs indicating the second and third classes of obesity experienced more depression, whereas obesity seemed to be associated with a lower risk of depression in older men. Obesity is also associated with several chronic diseases, most of which are related to psychiatric diseases. Zhao et al. [17] stated that the prevalence of depression and anxiety appeared to depend on various BMI levels regardless of the population's disease status and other psychosocial and lifestyle factors.

Our study investigated the relationship between depression and severe obesity. Our findings are valuable because we found that the examinees had lost their ability to work due to serious obesity.

\section{Materials and Methods}

The aims of this research were to study the individuals who are living in southern Finland and were receiving a permanent disability pension primarily due to obesity. 112 individuals ( 81 women and 31 men) fill in claim. The controls were selected by random sampling and matched with subjects according to place of residence and sex. The matching process also considered age, time that pension was granted, and occupation. The occupation of the controls was either the same as the subjects or unknown. The control group was selected from the same area and consisted of individuals receiving a disability pension due to a different primary illness. One hundred and fifty-two individuals met these criteria. Nineteen had been granted a temporary pension and were excluded from the sample. Participants who died or no longer received a pension were also excluded. Because men constituted a small group, many controls were selected to ensure a reliable analysis [1]. 
This study was a case-control study. Three controls were selected for each female subject, and five controls were selected for each male subject to obtain more reliable results. It is notable that male and female controls were selected separately. For the interview, we aimed to include at least two controls for each female subject and three for each male subject. Overall, the study enlisted 510 persons, including 112 subjects and 398 controls [1].

Three letters inviting individuals to participate in the study were sent to each subject and control. The letters were discreetly worded and emphasized the confidentiality of the study. Most individuals who did not participate in the study indicated their reasons for refusal in writing. These letters are available upon request [1].

Table 1 shows the basic characteristics of the study participants [2].

The accumulation of all materials is shown in Figure 1.

The age distribution of matched material is shown in Figure 2.

Body mass index (BMI) was calculated as weight $(\mathrm{kg})$ divided by height $\left(\mathrm{m}^{2}\right)$. According to the WHO guidelines, the weight categories were defined as follows: overweight, BMI $25 \leq 29$; obese, BMI $30 \leq 34$; severely obese, BMI $35 \leq 40$; and morbidly obese, BMI $>40 \mathrm{~kg} / \mathrm{m}^{2}$ [1]. Figure 3 shows the body mass index distribution in this study.
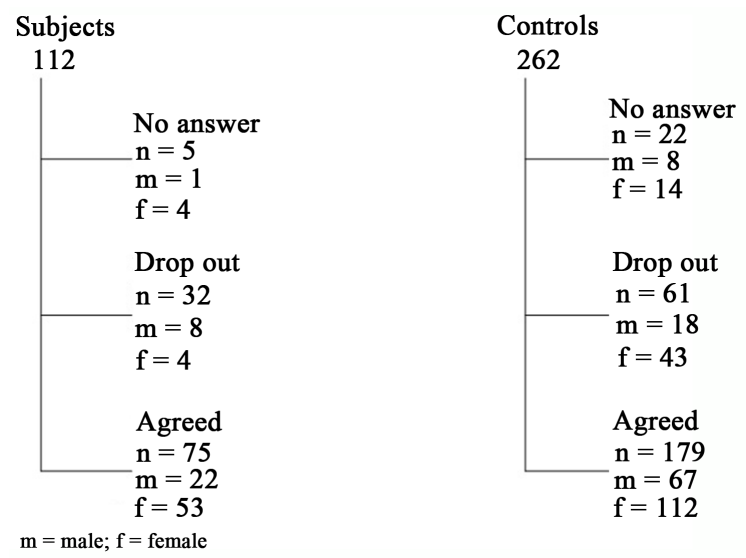

Figure 1. Study overview.

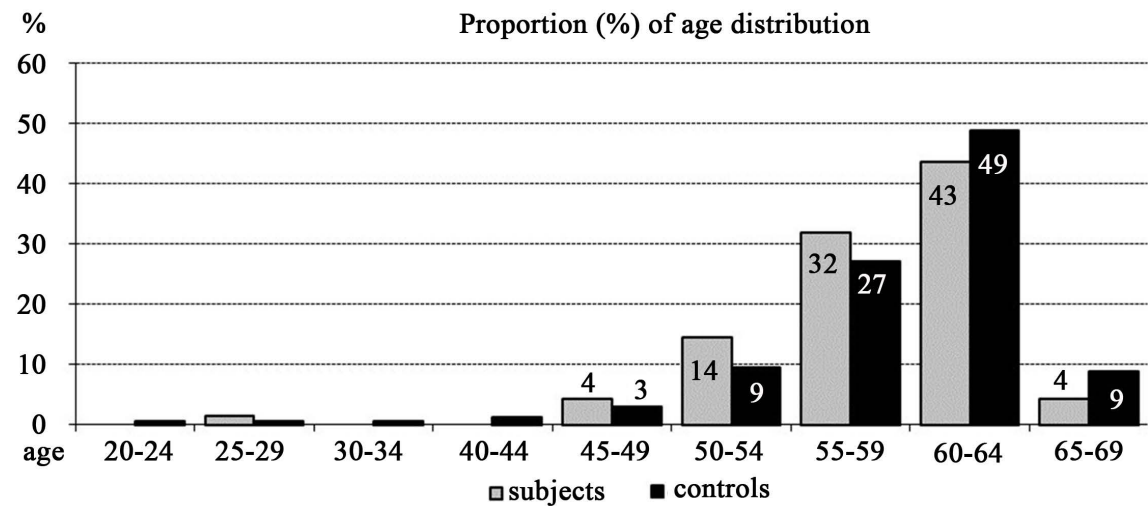

Figure 2. Age during the psychiatric examination. 
Table 1. Basic characteristics of the study participants.

\begin{tabular}{|c|c|c|c|}
\hline & Study group & Control group & $\begin{array}{l}\text { Significance } \\
\quad\left(\chi^{2} \text {-test }\right)\end{array}$ \\
\hline Marital status & & & $p=0.0894$ \\
\hline Unmarried & $10.7 \%$ & $15.7 \%$ & \\
\hline Married & $62.7 \%$ & $59.6 \%$ & \\
\hline Widowed & $14.7 \%$ & $13.5 \%$ & \\
\hline Divorced & $6.7 \%$ & $10.7 \%$ & \\
\hline Common-law marriage & $5.3 \%$ & $0.6 \%$ & \\
\hline Basic education & & & $p=0.2457$ \\
\hline Primary school & $89.3 \%$ & $90.4 \%$ & \\
\hline Lower secondary school & $6.7 \%$ & $2.2 \%$ & \\
\hline High school & - & $2.2 \%$ & \\
\hline Other & $4 \%$ & $3.9 \%$ & \\
\hline Occupational category & $\begin{array}{l}\mathrm{n}=22(\mathrm{~m}) \\
\mathrm{n}=53(\mathrm{f})\end{array}$ & $\begin{array}{l}\mathrm{n}=66(\mathrm{~m}) \\
\mathrm{n}=112(\mathrm{f})\end{array}$ & $\begin{array}{l}p=0.901(\mathrm{~m}) \\
p=0.5930(\mathrm{f})\end{array}$ \\
\hline $\begin{array}{l}\text { Technical, scientific, } \\
\text { sociological, } \\
\text { and artistic work }\end{array}$ & $\begin{array}{c}\mathrm{m}=0 \% \\
\mathrm{f}=0 \% \\
\text { total }=0 \%\end{array}$ & $\begin{array}{c}\mathrm{m}=0 \% \\
\mathrm{f}=4.5 \% \\
\text { total }=2.2 \%\end{array}$ & \\
\hline $\begin{array}{l}\text { Accounting and } \\
\text { clerical work }\end{array}$ & $\begin{array}{c}\mathrm{m}=4.5 \% \\
\mathrm{f}=5.7 \% \\
\text { total }=5.1 \%\end{array}$ & $\begin{array}{c}\mathrm{m}=1.5 \% \\
\mathrm{f}=2.7 \% \\
\text { total }=2.1 \%\end{array}$ & \\
\hline Commercial work & $\begin{array}{c}\mathrm{m}=4.5 \% \\
\mathrm{f}=17.0 \% \\
\text { total }=10.8 \%\end{array}$ & $\begin{array}{c}\mathrm{m}=4.5 \% \\
\mathrm{f}=10.7 \% \\
\text { total }=7.6 \%\end{array}$ & \\
\hline $\begin{array}{l}\text { Agricultural, forestry, } \\
\text { and fishing }\end{array}$ & $\begin{array}{c}\mathrm{m}=0 \% \\
\mathrm{f}=7.5 \% \\
\text { total }=3.7 \%\end{array}$ & $\begin{array}{c}\mathrm{m}=3.0 \% \\
\mathrm{f}=7.1 \% \\
\text { total }=5.1 \%\end{array}$ & \\
\hline $\begin{array}{l}\text { Transport and } \\
\text { communication work }\end{array}$ & $\begin{array}{c}\mathrm{m}=27.3 \% \\
\mathrm{f}=7.5 \% \\
\text { total }=17.4 \%\end{array}$ & $\begin{array}{c}\mathrm{m}=24.2 \% \\
\mathrm{f}=4.5 \% \\
\text { total }=14.3 \%\end{array}$ & \\
\hline Industrial work & $\begin{array}{c}\mathrm{m}=50.1 \% \\
\mathrm{f}=17.0 \% \\
\text { total }=33.5 \%\end{array}$ & $\begin{array}{c}\mathrm{m}=48.6 \% \\
\mathrm{f}=21.4 \% \\
\text { total }=35.0 \%\end{array}$ & \\
\hline Service work & $\begin{array}{c}\mathrm{m}=13.6 \% \\
\mathrm{f}=45.3 \% \\
\text { total }=29.5 \%\end{array}$ & $\begin{array}{c}\mathrm{m}=18.2 \% \\
\mathrm{f}=49.1 \% \\
\text { total }=33.7 \%\end{array}$ & \\
\hline Total & $\begin{array}{c}\mathrm{m}=100 \% \\
\mathrm{f}=100 \% \\
\text { total }=100 \%\end{array}$ & $\begin{array}{c}\mathrm{m}=100 \% \\
\mathrm{f}=100 \% \\
\text { total }=100 \%\end{array}$ & \\
\hline Social classification & $\begin{array}{l}\text { According to Bruun's } \\
\text { social classification }\end{array}$ & & $\begin{array}{c}p=0.050(\mathrm{~m}) \\
p=0.936(\mathrm{f})\end{array}$ \\
\hline $\mathrm{I}=$ First social class & $4.2 \%$ & $2.3 \%$ & \\
\hline $\mathrm{II}=$ Second social class & $12.5 \%$ & $17.7 \%$ & \\
\hline $\mathrm{III}=$ Third social class & $50.0 \%$ & $57.7 \%$ & \\
\hline IV $=$ Fourth social class & $33.3 \%$ & $22.3 \%$ & \\
\hline
\end{tabular}

$\mathrm{m}=$ male, $\mathrm{f}=$ female. 


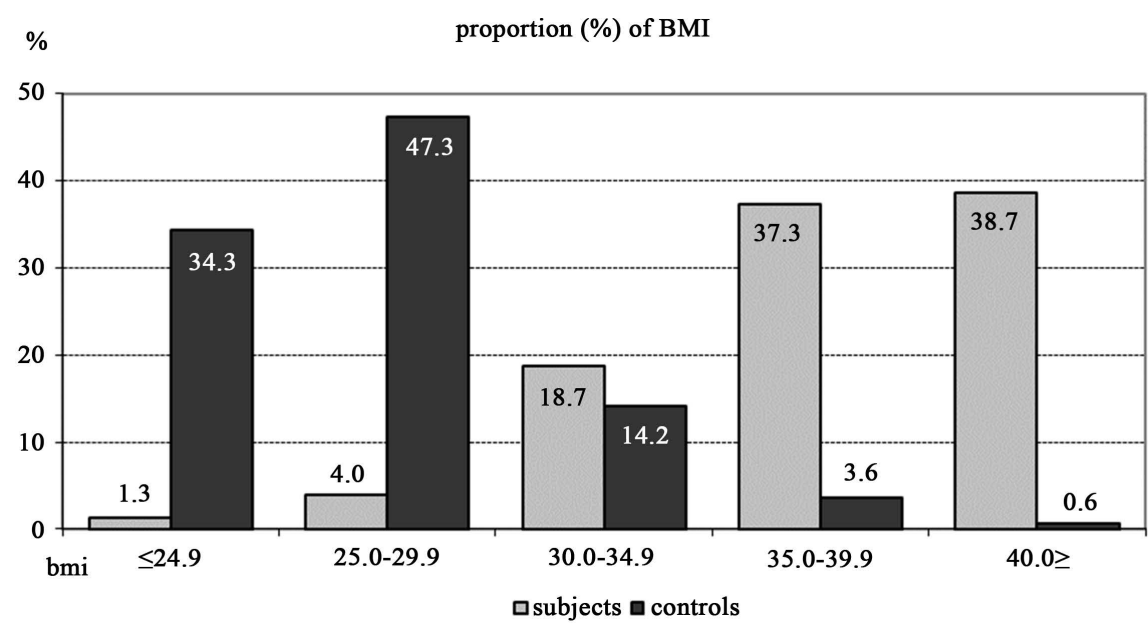

Figure 3. Body mass index distribution between subjects and controls.

\subsection{Interview Form}

The authors of this paper interviewed all participants. The pilot study $(\mathrm{n}=30)$ was conducted in the neurological ward of Hesperia Hospital in Helsinki. The subjects were patients at the hospital [2].

The Diagnostic and Statistical Manual of Mental Disorders (DSM-III) recommends using a multi-axial system for evaluations to ensure that certain potentially valuable information for treatment planning and outcome prediction is recorded for each individual on the five axes outlined in the DSM. The first three axes constitute an official diagnostic evaluation. Axes I and II include all mental disorders, and personality disorders, and specific developmental disorders are grouped into Axis II [18].

Occupation: The standard occupational classifications of the Social Insurance Institution (Bruun [19]) were used.

A disability pension is payable to insured individuals (due to disease, disability, or injury) who are unable to maintain themselves through regular work or any other type of suitable work based on their age, occupation, education and place of residence. The determining factors are type of disease, age, length of service, deterioration of health, and working conditions. A special team at the Social Insurance Institution decides individuals' pension eligibility [20].

\subsection{The Beck Depression Inventory}

After the interview, the participants completed the Beck Depression Inventory (BDI), as proposed by Beck et al. [21], which was used to measure depression. The inventory consisted of 21 questions, and each question had four to six response options. An additional factor, weight gain, was added to the original BDI by Raitasalo [22] in 1977 because the BDI addressed only weight loss.

The patients who had gained weight had difficulty answering the original questions, which addressed only losing weight. The questions measured the quantitative aspects of depression and the severity of depressive symptoms regarding the most common characteristics of patients with depression observed 
in clinical practice (M.K.).

\subsection{Statistical Methods}

The statistical methods used in this study included $\chi^{2}$-tests, $t$-tests and conditional logistic linear models. Because the subjects were matched, we analyzed the data with figures and percentages and through calculations of the means for the subjects and controls using a matched control approach. These two groups were then compared using $t$-test for paired variables. Significant T-test results were detected and analyzed further in the conditional logistic linear model. The risk ratios (RRs) and upper and lower confidence limits were calculated for parameters that remained significant in the conditional logistic linear analysis. The statistical parameters were calculated with SPSS (Statistical Package for Social Sciences for Windows 18/Windows, Chicago, IL, USA). The conditional logistic analyses were performed with the Glim program [23]. GLIM analysis is straightforward when the data are in a convenient individual-by-individual format, which commonly corresponds to the method compilation. A major advantage of this technique is that it is easy to use and has inherent flexibility [1] [2].

In each set, one case was included for every 0 - 5 controls. Because these observations were considered counts, a Poisson error distribution was used, and the logarithmic function was used as the link function. The model was a special form of the log-linear model. The linear predictor in the systematic part of the model for each observation was a (linear) function of the observed exposure variables for each individual plus a constant (set) term, which could vary from matched set to matched set. According to the literature regarding case-control data, this model is called a "conditional logistic regression" (which is a misleading description for data analysts who are familiar with generalized linear model terminology). Although the group of subjects would have remained very small with this method, the missing controls were replaced with the nearest control. The matched control approach meant that some of the subjects who had agreed to participate were excluded from the study during the statistical analysis because a control was not available. In some cases, specific variables were lacking, and the number of observations available for comparisons was further reduced [24]. Differences between groups were considered highly significant when the probability $(p)$ of error in rejecting the null hypothesis was $p<0.001\left(^{* * *}\right)$, significant when $p<0.01\left(^{* *}\right)$, and nearly significant when $p<0.05\left(^{*}\right)$ [1] [2].

The study protocol was approved by the ethical committees of Hesperia/ Aurora Hospital (Community Psychiatric Hospital in Helsinki) and Lapinlahti Hospital (Psychiatric Clinic of Helsinki University)/Psychiatric Centrum of Helsinki University. An informed consent form was signed by the patients, and the ethical principles of the Declaration of Helsinki were followed throughout the study [1].

\subsection{Refusal}

The individuals who refused to participate to this study had the same education 
level, age and sex distribution as the participating individuals. One male subject could not be contacted after initial inclusion in the study, and one female subject dropped out of the study before the psychological test was administered. 37 individuals refused to participate ( 9 males and 28 females) in the study. The mean ages of the male and female participants who refused to participate in the study group were 59 years (standard deviation (SD), 3.61) and 61 years (SD, 4.46) years, respectively. A total of 31 participants had a primary school level of education, and 34 had no vocational education. More matched controls than subjects refused to participate in this study. The complete information for the participants of this study is in the Table 1 [2].

\section{Results}

Depression was divided into four subclasses based on the DSM III. Table 2 illustrates the outcomes regarding depression. Chronic depression (dysthymia disorder) accounted for $28 \%$ of subjects and $14 \%$ of the controls. Additionally, 21 women and 6 men were diagnosed with mood disorders. Based on the conditional logistic linear model, individuals with severe obesity had a higher risk of depression than persons in the control group.

Table 2 shows the RRs, namely, chronic depression 2.1, other mood disturbance 6.6, and serious mood disturbance 6.0.

Table 3 illustrates the BDI classifications $(0-4) ; 11 \%$ of the subjects and $11 \%$ of the controls had severe depression. Eleven percent of the subjects and $9 \%$ of the controls had moderate depression. In the subject group, $7 \%$ had masked depression, and the corresponding figure in the control group was 5\%. Using $\mathcal{X}^{2}$ tests, no significant differences were found between the groups or between females and males.

Based on the conditional logistic linear model, no differences were observed between the study group and control group. No study vs. control group differences were observed when men and women were considered separately.

Table 4 shows the results of the BDI, which includes twenty-one questions. Comparisons between the study group and the control group were assessed with $\chi^{2}$ test (these questions were investigated separately). The differences in question eleven $(p=0.0283)$, which measures irritability, were almost significant, where $60.8 \%$ of the study group vs. $47.1 \%$ of the control group did not feel more irritated

Table 2. Outcome of depression in the psychiatric interview.

\begin{tabular}{|c|c|c|c|c|}
\hline \multirow{2}{*}{$\begin{array}{c}\text { Occurrence of } \\
\text { mood disturbances }\end{array}$} & Study group & Control group & \multirow{2}{*}{$\mathrm{RR}$} & \multirow{2}{*}{$\begin{array}{c}\text { 95\% } \\
\text { conf. limit }\end{array}$} \\
\hline & $\mathrm{n}=75$ & $\mathrm{n}=178$ & & \\
\hline Chronic depression & $28 \%$ & $14 \%$ & 2.1 & $1.3-3.5$ \\
\hline Other mood disturbance & $7 \%$ & $2 \%$ & 6.6 & $2.6-16.5$ \\
\hline Serious mood disturbance & $4 \%$ & $1 \%$ & 6.0 & $1.4-14.3$ \\
\hline None & $61 \%$ & $83 \%$ & - & - \\
\hline
\end{tabular}


Table 3. Outcome of depression in the beck depression inventory.

\begin{tabular}{|c|c|c|c|c|c|}
\hline \multirow{2}{*}{$\begin{array}{l}\text { Beck Depression } \\
\text { Inventory }\end{array}$} & \multicolumn{2}{|c|}{ Study group } & \multicolumn{2}{|c|}{ Study group } & \multirow{2}{*}{$\begin{array}{c}\chi^{2} \text {-test } \\
p=0.960 \\
p=0.853(\mathrm{~m}) \\
p=0.778(\mathrm{f})\end{array}$} \\
\hline & & & & & \\
\hline Masked depression & $7 \%$ & $\begin{array}{c}m=5 \% \\
f=8 \%\end{array}$ & $5 \%$ & $\begin{array}{c}\mathrm{m}=8 \% \\
\mathrm{f}=4 \%\end{array}$ & \\
\hline No depression & $49 \%$ & $\begin{array}{c}\mathrm{m}=50 \% \\
\mathrm{f}=49 \%\end{array}$ & $54 \%$ & $\begin{array}{c}\mathrm{m}=59 \% \\
\mathrm{f}=50 \%\end{array}$ & \\
\hline Slight depression & $22 \%$ & $\begin{array}{c}\mathrm{m}=23 \% \\
\mathrm{f}=23 \%\end{array}$ & $21 \%$ & $\begin{array}{c}\mathrm{m}=15 \% \\
\mathrm{f}=25 \%\end{array}$ & \\
\hline Moderate depression & $11 \%$ & $\begin{array}{l}m=9 \% \\
f=11 \%\end{array}$ & $9 \%$ & $\begin{array}{c}m=9 \% \\
f=9 \%\end{array}$ & \\
\hline Severe depression & $11 \%$ & $\begin{aligned} \mathrm{m} & =13 \% \\
\mathrm{f} & =9 \%\end{aligned}$ & $11 \%$ & $\begin{array}{l}m=9 \% \\
f=12 \%\end{array}$ & \\
\hline
\end{tabular}

$\mathrm{m}=$ male, $\mathrm{f}=$ female; ${ }^{* * *} p<0.001$, highly significant; ${ }^{* *} p<0.01$, significant; ${ }^{*} p<0.05$, nearly significant.

Table 4. Results of the beck depression inventory.

\begin{tabular}{|c|c|c|c|c|c|}
\hline \multirow{2}{*}{ All variables } & \multicolumn{2}{|c|}{ Study group } & \multicolumn{2}{|c|}{ Control group } & \multirow{2}{*}{$\frac{p \text {-value }}{\chi^{2} \text {-test }{ }^{*}}$} \\
\hline & $\mathrm{m}$ & $\mathrm{f}$ & $\mathrm{m}$ & $\mathrm{f}$ & \\
\hline 1) Sadness & 22 & 52 & 66 & 108 & $0.898^{\#}$ \\
\hline 2) Pessimism & 22 & 52 & 65 & 107 & 0.4498 \\
\hline 3) Past failure & 22 & 52 & 65 & 107 & 0.4355 \\
\hline 4) Loss of pleasure & 22 & 52 & 65 & 107 & $0.586^{\#}$ \\
\hline 5) Guilty feelings & 22 & 52 & 65 & 107 & 0.3745 \\
\hline 6) Punishment feelings & 22 & 52 & 65 & 107 & 0.9970 \\
\hline 7) Self-dislike & 22 & 52 & 65 & 108 & $0.782^{\#}$ \\
\hline 8) Self-criticalness & 22 & 52 & 66 & 107 & 0.2494 \\
\hline 9) Suicidal thoughts or wishes & 22 & 52 & 65 & 107 & $0.614^{\#}$ \\
\hline 10) Crying & 22 & 52 & 65 & 107 & 0.4102 \\
\hline 11) Irritability & 22 & 52 & 65 & 107 & 0.0283 \\
\hline 12) Loss of interest & 22 & 52 & 65 & 107 & $0.596^{\#}$ \\
\hline 13) Indecisiveness & 22 & 52 & 65 & 107 & 0.0573 \\
\hline 14) Body image & 22 & 52 & 65 & 107 & 0.0274 \\
\hline 15) Work inhibition & 22 & 52 & 65 & 107 & 0.0394 \\
\hline 16) Changes in sleeping pattern & 22 & 52 & 65 & 107 & 0.3408 \\
\hline 17 Fatigability & 22 & 52 & 65 & 107 & 0.1326 \\
\hline 18) Changes in appetite & 22 & 52 & 65 & 107 & $0.084^{\#}$ \\
\hline 19A) Weight loss & 22 & 52 & 65 & 107 & 0.014 \\
\hline 19B) Weight gain & 10 & 22 & 18 & 38 & 0.017 \\
\hline 20) Somatic preoccupation & 22 & 52 & 65 & 107 & $0.094^{\#}$ \\
\hline 21) Loss of interest in sex & 22 & 52 & 65 & 107 & 0.7346 \\
\hline
\end{tabular}

${ }^{*}$ the value of $\chi^{2}$ test is a common result in study and control groups. ${ }^{*}$ For this question, all individuals with symptoms were combined. $(\mathrm{f}=$ female, $\mathrm{m}=$ male). 
than before. However, $36 \%$ of the control group felt irritated all the time compared to $23 \%$ in the study group. Nearly significant differences were observed for the question of indecisiveness $(p=0.0573)$. Question fourteen $(p=0.0274)$, which involves body image, found that $52.7 \%$ of the study group did not feel that they looked any worse than before, compared to $58.7 \%$ of the control group; additionally, $24.3 \%$ of the study group felt that there were permanent changes to their appearance that made them look unattractive, compared with $10.5 \%$ in the control group. Question fifteen ( $p=0.0394)$ showed that both the study and the control group felt that their ability to work had deteriorated, while $14.9 \%$ of the study group felt that they had to push themselves very hard to do anything. Closer attention should be paid to the results of question eighteen $(p=0.084)$, which showed that $24.3 \%$ of the study group felt that they had a poorer appetite.

Table 5 illustrates the weight changes reported on question 19 in the BDI. Question 19 indicated that over the previous weeks, weight had not changed in $44.2 \%$ of all participants, including both the study and the control group. Regarding weight loss, a significant difference between the study group and control group was found, at $p=0.014$, while the significance was $p=0.017$ for weight gain, both of which are nearly statistically significant. In females, $23.1 \%$ of the

Table 5. Weight changes in the beck depression inventory, question 19 in Table 4.

\begin{tabular}{|c|c|c|c|c|c|c|c|c|c|}
\hline & $\begin{array}{c}\text { Study } \\
\text { group } \\
\mathrm{n}=74 \\
\text { (all) }\end{array}$ & $\begin{array}{c}\text { Control } \\
\text { group } \\
\mathrm{n}=171 \\
\text { (all) }\end{array}$ & $\begin{array}{c}\text { Total } \\
\mathbf{n}=\mathbf{2 4 5} \\
(\text { all })\end{array}$ & $\begin{array}{c}\text { Study } \\
\text { group } \\
\mathrm{n}=\mathbf{5 2} \\
\text { (f) }\end{array}$ & $\begin{array}{c}\text { Control } \\
\text { group } \\
\mathrm{n}=107 \\
\text { (f) }\end{array}$ & $\begin{array}{c}\text { Total } \\
\mathbf{n}=159 \\
(f)\end{array}$ & $\begin{array}{c}\text { Study } \\
\text { group } \\
\mathrm{n}=22 \\
(\mathrm{~m})\end{array}$ & $\begin{array}{l}\text { Control } \\
\text { group } \\
\mathrm{n}=64 \\
(\mathrm{~m})\end{array}$ & $\begin{array}{c}\text { Total } \\
\mathbf{n}=\mathbf{8 6} \\
(\mathrm{m})\end{array}$ \\
\hline $\begin{array}{c}\mathrm{n}=\text { Weight } \\
\text { decreased }\end{array}$ & 17 & 14 & 31 & 12 & 8 & 20 & 5 & 6 & 11 \\
\hline more than $6 \mathrm{~kg}$ & $23.0 \%$ & $8.2 \%$ & $12.7 \%$ & $23.1 \%$ & $7.5 \%$ & $12.6 \%$ & $22.7 \%$ & $9.4 \%$ & $12.8 \%$ \\
\hline $\begin{array}{c}\mathrm{n}=\text { Weight } \\
\text { decreased }\end{array}$ & 3 & 8 & 11 & 3 & 4 & 7 & 0 & 4 & 4 \\
\hline more than $4 \mathrm{~kg}$ & $4.1 \%$ & $4.7 \%$ & $4.5 \%$ & $5.8 \%$ & $3.7 \%$ & $4.4 \%$ & $.0 \%$ & $6.3 \%$ & $4.7 \%$ \\
\hline $\begin{array}{c}\mathrm{n}=\text { Weight } \\
\text { decreased }\end{array}$ & 4 & 14 & 18 & 3 & 9 & 12 & 1 & 5 & 6 \\
\hline more than $2 \mathrm{~kg}$ & $5.4 \%$ & $8.2 \%$ & $7.3 \%$ & $5.8 \%$ & $8.4 \%$ & $7.5 \%$ & $4.5 \%$ & $7.8 \%$ & $7.0 \%$ \\
\hline $\begin{array}{c}\mathrm{n}=\text { Weight } \\
\text { did not }\end{array}$ & 18 & 80 & 98 & 12 & 48 & 60 & 6 & 32 & 38 \\
\hline change & $24.3 \%$ & $46.8 \%$ & $40.0 \%$ & $23.1 \%$ & $44.9 \%$ & $37.7 \%$ & $27.3 \%$ & $50.0 \%$ & $44.2 \%$ \\
\hline $\begin{array}{c}\mathrm{n}=\text { Weight } \\
\text { increased more }\end{array}$ & 3 & 7 & 10 & 2 & 5 & 7 & 1 & 2 & 3 \\
\hline than $2 \mathrm{~kg}$ & $4.1 \%$ & $4.1 \%$ & $4.1 \%$ & $3.8 \%$ & $4.7 \%$ & $4.4 \%$ & $4.5 \%$ & $3.1 \%$ & $3.5 \%$ \\
\hline $\begin{array}{c}\mathrm{n}=\text { Weight } \\
\text { increased }\end{array}$ & 4 & 21 & 25 & 3 & 17 & 20 & 1 & 4 & 5 \\
\hline more than $4 \mathrm{~kg}$ & $5.4 \%$ & $12.3 \%$ & $10.2 \%$ & $5.8 \%$ & $15.9 \%$ & $12.6 \%$ & $4.5 \%$ & $6.3 \%$ & $5.8 \%$ \\
\hline $\begin{array}{c}\mathrm{n}=\text { Weight } \\
\text { increased }\end{array}$ & 25 & 27 & 52 & 17 & 16 & 33 & 8 & 11 & 19 \\
\hline more than $6 \mathrm{~kg}$ & $33.8 \%$ & $15.8 \%$ & $21.2 \%$ & $32.7 \%$ & $15.0 \%$ & $20.8 \%$ & $36.4 \%$ & $17.2 \%$ & $22.1 \%$ \\
\hline
\end{tabular}

$\mathrm{f}=$ female, $\mathrm{m}=$ male. 
study group had lost more than $6 \mathrm{~kg}$ of weight, and $32.7 \%$ had gained more than $6 \mathrm{~kg}$ of weight during the pension period. In the male study group, the results were similar; $22.7 \%$ had lost more than $6 \mathrm{~kg}$ of weight and 36.4\% had gained more than $6 \mathrm{~kg}$ of weight $(p=0.190)$ in the previous weeks. Among individuals in the study group with a BMI $\geq 40 \mathrm{~kg} / \mathrm{m}^{2}, 37.9 \%$ had gained more weight and only $6.9 \%$ had lost weight.

\section{Discussion}

\subsection{Statement of Principal Findings}

Depression was diagnosed more in the subject group than in the control group based on the psychiatric interview. In the conditional logistic linear model, individuals with severe obesity had a higher risk of depression than persons in the control group. The most common disturbance was chronic depression in both groups. Statistically significant findings regarding the outcome of depression were also observed for every classification in the psychiatric interview. We found more masked depression in the study group.

Based on the distribution of depression in the sample according to the BDI, the subject group suffered from depression more often than the control group. However, slight depression was the most common in the study group. Seven percent of the subjects had masked depression.

The BDI questions measuring irritability, indecisiveness, body image and ability to work were nearly significant. Regarding weight changes, as assessed in the Beck Depression Inventory questions, both weight loss and weight gain were statistically significant.

In the study group, individuals with BMI over $40 \mathrm{~kg} / \mathrm{m}^{2}$ gained the most weight. Weight loss was very low. On the question regarding change in appetite, the majority of the study group answered that their appetite was worse than it had been before.

\subsection{Strengths and Weaknesses of the Study}

The participants of this study were not obtained from a diet group, as in most obesity research. This approach enhanced the validity of the findings. The subjects in this study were concentrated on a group of individuals receiving a disability pension due to obesity. The study group was successfully matched with the control group. The occupational and social statuses of both groups were nearly the same. The influence of the subject's life situation was minimized because members of the control group had also been receiving a pension for the same duration. All subjects were interviewed individually, which tends to improve the reliability of the results. The interview was conducted to ensure that the interviewer did not know whether the participant was a subject or control. This double-blind approach increased the validity of the study. The fact that controls were selected by random sampling using data from the Social Insurance Institution of Finland adds value to the findings [1] [2]. 


\subsection{Strength and Weakness in Relation to Other Studies and a Discussion of Differences in the Results}

Similar results regarding the relationship between obesity and depression were found by Beydoun and Wang [25]. According to Ma and Xiao [12], obesity is an especially important risk factor for depression in obese female individuals with BMI class 3 obesity. Chen et al. [5] demonstrated that the prevalence of depression was higher in women than men. According to Murphy et al. [26], depression was much more severe in obese individuals than in non-obese individuals.

Werrij et al. [27] also used the BDI to study depression and obesity. In addition, Krukowski et al. [28] found that the BDI effectively predicted which obese individuals had depression. Furthermore, Castellini et al. [29] demonstrated that the BDI had high prevalence rates when symptoms of depression and anxiety were present. Researchers [30] have used the BDI to assess depression symptoms in binge eating and obesity groups. They used both 21- and 16-item versions of the Fourth Edition Axis I Disorders. All three measures had the potential to inform depression features. According to Xiang [31], obese older adults have the potential to become depressed. Degirmenci [32] found that depression and anxiety levels were high among individuals who had obesity. Their results suggest that psychiatric care may have positive effects on quality of life and self-esteem in individuals with obesity.

Some studies have published results that differ from those in our study. According to Hung et al. [33], obesity is associated with depression and higher BMI increases the risk of mental illnesses. The results of this study (M.K.) differed from those of Mattlar et al. [34], and the author (M.K.) has different views than those of Ma and Xiao [12]. Sarwer et al. [35] found that two-thirds of morbidly obese individuals had a psychiatric diagnosis, often major depressive disorder. We did not find the same results. Stunkard et al. [36] identified an association between obesity and major depressive disorder. Our results also differ from Kaplan et al. [37], who found that very few obese non-binge-eaters suffered from depression. Istvan et al. [38] observed that depression was only weakly correlated with BMI among women and not at all among men. In this study (M.K.), depression was more common in women than in men, and the results were therefore not fully consistent with the abovementioned opinions.

In Kaplan et al.'s [37] study, some forms of depression, particularly mood disorders with a seasonal pattern, were associated with weight gain (seasonal affective disorder). Thus, weight change may be a marker of subtypes of depressive disorders. Depression is more severe among obese compared with non-obese individuals. Weight gain in obese individuals is an important marker of depression severity, as reported by Murphy et al. [26] Marmorstein et al. [39] found that adolescence is the time when MDD becomes more prevalent and that depression also increases in adulthood. We did not observe these findings in our study.

In their research, Ahmadi et al. [40] found that total body fat was remarkably higher in women with depression than in those without. However, total body fat 
is not associated with BMI and the geriatric depression scale (GDS). According to Roberts and Duong [41], it is more important to research body image components in depression and obesity than BMI and depression; the findings in this study were highly consistent with those observed by Roberts and Duong. In this research (M.K.), the findings differ from those of Zimmerman [13] because of the research frame used. The author of this study (M.K.) had different attitudes than those of Faulconbridge et al. [14] but partly the same opinions as Wild [16].

However, the psychiatric interview revealed the same characteristics as in the Achte [18] study. These types of studies are rare, and therefore there is thus no further data that can be used to compare the findings.

\subsection{Meaning of the Study: Possible Mechanisms and Implication for Clinicians or Policy Makers}

Obesity and depression are both diseases of civilization, and their development and maintenance are highly influenced by dysregulations of neuroimmunological parameters and physiological regulatory processes. Therapeutic methods should always be consistent with current evidence from studies and should be tailored to patients' individualized situations [42]. According to researchers, heterogeneity in depression must be observed when examining the impact of depression on obesity in older age. As a preventive procedure, older adults with atypical depression should be assessed [43]. In weight loss meetings, MDD has been shown to predict worse weight loss outcomes. In women with MDD and obesity, worse quality diet was associated with depression but not physical activity [44]. According to Hamer et al. [45], metabolic health is a risk factor for the development of depression and obesity. This finding is not global, and more studies are needed to support these results. Brunault et al. [46] in their research on a group receiving surgery highlight that depression and binge eating should be identified before operations. Lasserre et al. [47] found that the atypical subtype of MDD is a strong predictor of obesity. The Montgomery-Asberg Depression Rating Scale (MADRS) measures the degree of depression; this measure is recommended as a preventive method before bariatric surgery [48]. Esposito et al. [49] highlighted the importance of assessing the presence of internalizing problems such as anxiety and depression in childhood obesity.

\subsection{Unanswered Questions and Future Research}

Although depression is known to have a significant relationship with morbid obesity, how depression status changes after losing weight in surgical operations remains unknown [50]. According to Chapman et al. [51], mental illnesses, specifically depressive disorders, are more prevalent in chronic diseases. Chronic disease management and the treatment of depression are connected. Age and gender differences need to be taken into consideration when examining the associations of BMI or obesity with common mental disorders [52]. Siwek et al. [53] found that the connection between obesity and bipolar spectrum disorders should be further researched. According to Rossetti et al. [54], preclinical and 
clinical studies illustrate that eating disorders are associated with mood disturbances. Zelder et al. [55] showed that obesity is associated with depression in premenopausal women. These 2 risk factors should be considered in preventive methods for cardiovascular disorders.

We should investigate the connection of obesity with masked depression and indirect suicide in the future.

\section{Conclusion}

In our opinion, this study provides a new and needed overview of the relationship between depression and severe obesity. These findings were necessary and provided insight into groups that had not been previously examined. The results of this research can be utilized to improve the care and understanding of individuals with severe obesity.

\section{References}

[1] Koski, M. and Naukkarinen, H. (2017) Severe Obesity, Emotions and Eating Habits: A Case-Control Study. BMC Obesity, 4, 2. https://doi.org/10.1186/s40608-016-0138-9

[2] Koski, M. and Naukkarinen, H. (2017) The Relationship between Stress and Severe Obesity: A Case-Control Study. Biomedicine Hub. https://doi.org/10.1159/000458771

[3] Zhang, Y., Liu, J., Yao, J., Ji, G., Qian, L., Wang, J., Zhang, G., Tian, J., Nie, Y., Zhang, Y.E., Gold, M.S. and Liu, Y. (2014) Obesity: Pathophysiology and Intervention. Nutrients, 6, 5153-5183. https://doi.org/10.3390/nu6115153

[4] Milaneschi, Y., Simonsick, E.M., Vogelzangs, N., Strotmeyer, E.S., Yaffe, K., Harris, T.B., Tolea, M.I., Ferrucci, L. and Penninx, B.W. (2012) Leptin, Abdominal Obesity, and Onset of Depression in Older Men and Women. Journal of Clinical Psychiatry, 73, 1205-1211. https://doi.org/10.4088/JCP.11m07552

[5] Chen, Y., Jiang, Y. and Mao, Y. (2009) Association between Obesity and Depression in Canadians. Journal of Women's Health, 18, 1687-1692.

https://doi.org/10.1089/jwh.2008.1175

[6] Mauri, M., Rucci, P., Calderone, A., Santini, F., Oppo, A., Romano, A., Rinaldi, S., Armani, A., Polini, M., Pinchera, A. and Cassano, G.B. (2008) Axis I and II Disorders and Quality of Life in Bariatric Surgery Candidates. Journal of Clinical Psychiatry, 69, 295-301. https://doi.org/10.4088/JCP.v69n0216

[7] Gadalla, T.M. (2009) Association of Obesity with Mood and Anxiety Disorders in the Adult General Population. Chronic Diseases in Canada, 30, 29-36.

[8] Jorm, A.F., Korten, A.E., Christensen, H., Jacomb, P.A., Rodgers, B. and Parslow, R.A. (2003) Association of Obesity with Anxiety, Depression and Emotional Well-Being: A Community Survey. Australian and New Zealand Journal of Public Health, 27, 434-440. https://doi.org/10.1111/j.1467-842X.2003.tb00423.x

[9] Kalarchian, M.A., Marcus, M.D., Levine, M.D., Soulakova, J.N., Courcoulas, A.P. and Wisinski, M.S. (2008) Relationship of Psychiatric Disorders to 6-Month Outcomes after Gastric Bypass. Surgery for Obesity and Related Diseases, 4, 544-549. https://doi.org/10.1016/j.soard.2008.03.003

[10] Farberow, N.L. and Williams, J. (1983) Indirect Self-Destructive Behavior and the Hyperobese. Psychiatria Fennica, Supplementum 21-39. 
[11] Achté, K. (1983) Types of Indirect Self-Destruction. Psychiatrica Fennica, Supplementum, 41-44.

[12] Ma, J. and Xiao, L. (2010) Obesity and Depression in US Women: Results from the 2005-2006 National Health and Nutritional Examination Survey. Obesity, 18, 347353. https://doi.org/10.1038/oby.2009.213

[13] Zimmerman, M., Hrabosky, J.I., Francione, C., Young, D., Chelminski, I., Dalrymple, K. and Galione, J.N. (2011) Impact of Obesity on the Psychometric Properties of the Diagnostic and Statistical Manual of Mental Disorders, Fourth Edition Criteria for Major Depressive Disorder. Comprehensive Psychiatry, 52, 146-150. https://doi.org/10.1016/j.comppsych.2010.05.001

[14] Faulconbridge, L.F., Wadden, T.A., Rubin, R.R., Wing, R.R., Walkup, M.P., Fabricatore, A.N., Coday, M., Van Dorsten, B., Mount, D.L. and Ewing, L.J. (2012) One-Year Changes in Symptoms of Depression and Weight in Overweight/Obese Individuals with Type 2 Diabetes in the Look AHEAD Study. Obesity, 20, 783-793. https://doi.org/10.1038/oby.2011.315

[15] Fowler-Brown, A.G., Ngo, L.H. and Wee, C.C. (2012) The Relationship between Symptoms of Depression and Body Weight in Younger Adults. Obesity, 20, 1922 1928. https://doi.org/10.1038/oby.2011.311

[16] Wild, B., Herzog, W., Lechner, S., Niehoff, D., Brenner, H., Muller, H., Rothenbacher, D., Stegmaier, C. and Raum, E. (2012) Gender Specific Temporal and Cross-Sectional Associations between BMI-Class and Symptoms of Depression in the Elderly. Journal of Psychosomatic Research, 72, 376-382. https://doi.org/10.1016/j.jpsychores.2012.01.019

[17] Zhao, G., Ford, E.S., Dhingra, S., Li, C., Strine, T.W. and Mokdad, A.H. (2009) Depression and Anxiety among US Adults: Associations with Body Mass Index. International Journal of Obesity, 33, 257-266. https://doi.org/10.1038/ijo.2008.268

[18] Frances, A. and Cooper, A.M. (1981) Descriptive and Dynamic Psychiatry: A Perspective on DSM-III. American Journal of Psychiatry, 138, 376-378.

[19] Bruun, K. (1954) Sosiaaliluokkajako. Tilastollisia Kuukausitietoja Helsingistä No: 3, Helsinki.

[20] Rinne, H.J. and Huunan-Seppälä, A. (1979) Työkyvyttömyyskysymyksen Arviointia. Sosiaalivakuutus, 6, 181-189.

[21] Beck, A.T., Ward, C.H., Mendelson, M., Mock, J. and Erbaugh, M.D. (1961) An Inventory for Measuring Depression. Archives of General Psychiatry, 4, 53-63. https://doi.org/10.1001/archpsyc.1961.01710120031004

[22] Raitasalo, R. (1977) Depression and Its Connections with the Need for Psychotherapy. Publication of Social Insurance Institution of Finland.

[23] Adena, M.A. and Wilson, S.R. (1982) Generalised Linear Models in Epidemiological Research: Case-Control Studies. The Intstat Foundation, Sydney.

[24] Armitage, P. (1971) Statistical Methods in Medical Research. Blackwell Scientific Publications, Oxford.

[25] Beydoun, M.A. and Wang, Y. (2010) Pathways Linking Socioeconomic Status to Obesity through Depression and Lifestyle Factors among Young US Adults. Journal of Affective Disorders, 123, 52-63. https://doi.org/10.1016/j.jad.2009.09.021

[26] Murphy, J.M., Horton, N.J., Burke, J.D., Monson Jr., R.R., Laird, N.M., Lesage, A. and Sobol, A.M. (2009) Obesity and Weight Gain in Relation to Depression: Findings from the Stirling County Study. International Journal of Obesity, 33, 335-341. https://doi.org/10.1038/ijo.2008.273 
[27] Werrij, M.Q., Mulkens, S., Hospers, H.J. and Jansen, A. (2006) Overweight and Obesity: The Significance of a Depressed Mood. Patient Education and Counseling, 62, 126-131. https://doi.org/10.1016/j.pec.2005.06.016

[28] Krukowski, R.A., Friedman, K.E. and Applegate, K.L. (2010) The Utility of the Beck Depression Inventory in a Bariatric Surgery Population. Obesity Surgery, 20, 426431. https://doi.org/10.1007/s11695-008-9717-2

[29] Castellini, G., Lapi, F., Ravaldi, C., Vannacci, A., Rotella, C.M., Faravelli, C. and Ricca, V. (2008) Eating Disorder Psychopathology Does Not Predict the Overweight Severity in Subjects Seeking Weight Loss Treatment. Comprehensive Psychiatry, 49, 359-363. https://doi.org/10.1016/j.comppsych.2008.01.005

[30] Udo, T., McKee, S.A. and Grilo, C.M. (2015) Factor Structure and Clinical Utility of the Beck Depression Inventory in Patients with Binge Eating Disorder and Obesity. General Hospital Psychiatry, 37, 120-125. https://doi.org/10.1016/j.genhosppsych.2014.11.011

[31] Xiang, X. and An, R. (2015) Obesity and Onset of Depression among U.S. Middle-Aged and Older Adults. Journal of Psychosomatic Research, 78, 242-248. https://doi.org/10.1016/j.jpsychores.2014.12.008

[32] Degirmenci, T., Kalkan-Oguzhanoglu, N., Sozeri-Varma, G., Ozdel, O. and Fenkci, S. (2015) Psychological Symptoms in Obesity and Related Factors. Archives of Neuropsychiatry/ Noropsikiatri Arsivi, 52, 42-46. https://doi.org/10.5152/npa.2015.6904

[33] Hung, C.F., Rivera, M., Craddock, N., Owen, M.J., Gill, M., Korszun, A., Maier, W., Mors, O., Preisig, M., Rice, J.P., Rietschel, M., Jones, L., Middleton, L., Aitchison, K.J., Davis, O.S., Breen, G., Lewis, C., Farmer, A. and McGuffin, P. (2014) Relationship between Obesity and the Risk of Clinically Significant Depression: Mendelian Randomisation Study. British Journal of Psychiatry, 205, 24-28. https://doi.org/10.1192/bjp.bp.113.130419

[34] Mattlar, C.-E., Salminen, J.K., Korhonen, M., Hellsten, E.R. and Knuts, L.-R. (1988) Personality, Morbid Obesity and Reducing. 1st European Congress on Obesity, Stockholm, 31-56.

[35] Sarwer, D.B., Cohn, N.I., Gibbons, L.M., Magee, L., Crerand, C.E., Raper, S.E., Rosato, E.F., Williams, N.N. and Wadden, T.A. (2004) Psychiatric Diagnoses and Psychiatric Treatment among Bariatric Surgery Candidates. Obesity Surgery, 14, 11481156. https://doi.org/10.1381/0960892042386922

[36] Stunkard, A.J., Faith, M.S. and Allison, K.C. (2003) Depression and Obesity. Biological Psychiatry, 54, 330-337. https://doi.org/10.1016/S0006-3223(03)00608-5

[37] Kaplan, H.I., Sadock, B.J. and Sadock, V.A. (2000) Kaplan \& Sadock's Comprehensive Textbook of Psychiatry. Lippincott Williams \& Wilkins, Philadelpia.

[38] Istvan, J., Zavela, K. and Weidner, G. (1992) Body Weight and Psychological Distress in NHANES I. International Journal of Obesity and Related Metabolic Disorders, 16, 999-1003.

[39] Marmorstein, N.R., Iacono, W.G. and Legrand, L. (2014) Obesity and Depression in Adolescence and Beyond: Reciprocal Risks. International Journal of Obesity, 38, 906911. https://doi.org/10.1038/ijo.2014.19

[40] Ahmadi, S.M., Keshavarzi, S., Mostafavi, S.A. and Bagheri Lankarani, K. (2015) Depression and Obesity/Overweight Association in Elderly Women: A Community-Based Case-Control Study. Acta Medica Iranica, 53, 686-689.

[41] Roberts, R.E. and Duong, H.T. (2015) Does Major Depression Affect Risk for Adolescent Obesity? Journal of Affective Disorders, 186, 162-167.

https://doi.org/10.1016/j.jad.2015.06.030 
[42] Thormann, J., Chittka, T., Minkwitz, J., Kluge, M. and Himmerich, H. (2013) Obesity and Depression: An Overview on the Complex Interactions of Two Diseases. Fortschritte der Neurologie-Psychiatrie, 81, 145-153.

[43] Chou, K.L. and Yu, K.M. (2013) Atypical Depressive Symptoms and Obesity in a National Sample of Older Adults with Major Depressive Disorder. Depress Anxiety, 30, 574-579. https://doi.org/10.1002/da.22098

[44] Appelhans, B.M., Whited, M.C., Schneider, K.L., Ma, Y., Oleski, J.L., Merriam, P.A., Waring, M.E., Olendzki, B.C., Mann, D.M., Ockene, I.S. and Pagoto, S.L. (2012) Depression Severity, Diet Quality, and Physical Activity in Women with Obesity and Depression. Journal of the Academy of Nutrition and Dietetics, 112, 693-698. https://doi.org/10.1016/j.jand.2012.02.006

[45] Hamer, M., Batty, G.D. and Kivimaki, M. (2012) Risk of Future Depression in People Who Are Obese but Metabolically Healthy: The English Longitudinal Study of Ageing. Molecular Psychiatry, 17, 940-945. https://doi.org/10.1038/mp.2012.30

[46] Brunault, P., Frammery, J., Couet, C., Delbachian, I., Bourbao-Tournois, C., Objois, M., Cosson, P., Reveillere, C. and Ballon, N. (2015) Predictors of Changes in Physical, Psychosocial, Sexual Quality of Life, and Comfort with Food after Obesity Surgery: A 12-Month Follow-Up Study. Quality of Life Research, 24, 493-501. https://doi.org/10.1007/s11136-014-0775-8

[47] Lasserre, A.M., Glaus, J., Vandeleur, C.L., Marques-Vidal, P., Vaucher, J., Bastardot, F., Waeber, G., Vollenweider, P. and Preisig, M. (2014) Depression with Atypical Features and Increase in Obesity, Body Mass Index, Waist Circumference, and Fat Mass: A Prospective, Population-Based Study. JAMA Psychiatry, 71, 880-888. https://doi.org/10.1001/jamapsychiatry.2014.411

[48] Paiva-Medeiros, P.F., Duarte-Guerra, L.S., Santo, M.A., Lotufo-Neto, F. and Wang, Y.P. (2015) Psychometric Properties of the Montgomery-Asberg Depression Rating Scale in Severely Obese Patients. Spanish Journal of Psychology, 18, E69. https://doi.org/10.1017/sjp.2015.072

[49] Esposito, M., Gallai, B., Roccella, M., Marotta, R., Lavano, F., Lavano, S.M., Mazzotta, G., Bove, D., Sorrentino, M., Precenzano, F. and Carotenuto, M. (2014) Anxiety and Depression Levels in Prepubertal Obese Children: A Case-Control Study. Neuropsychiatric Disease and Treatment, 10, 1897-1902.

[50] Deliopoulou, K., Konsta, A., Penna, S., Papakostas, P. and Kotzampassi, K. (2013) The Impact of Weight Loss on Depression Status in Obese Individuals Subjected to Intragastric Balloon Treatment. Obesity Surgery, 23, 669-675. https://doi.org/10.1007/s11695-012-0855-1

[51] Chapman, D.P., Perry, G.S. and Strine, T.W. (2005) The Vital Link between Chronic Disease and Depressive Disorders. Preventing Chronic Disease, 2, A14.

[52] McCrea, R.L., Berger, Y.G. and King, M.B. (2012) Body Mass Index and Common Mental Disorders: Exploring the Shape of the Association and Its Moderation by Age, Gender and Education. International Journal of Obesity, 36, 414-421. https://doi.org/10.1038/ijo.2011.65

[53] Siwek, M., Dudek, D., Jaeschke, R., Dembinska-Kiec, A., Witkowski, L., Arciszewska, A., Hebal, F., Matlok, M., Malczewska-Malec, M., Wnek, D., Pilecki, M., Major, P., Epa, R. and Rybakowski, J. (2015) Bipolar Spectrum Features in Obese Individuals. Psychiatria Polska, 49, 993-1004.

[54] Rossetti, C., Halfon, O. and Boutrel, B. (2014) Controversies about a Common Etiology for Eating and Mood Disorders. Frontiers in Psychology, 5, 1205. https://doi.org/10.3389/fpsyg.2014.01205 
[55] Zedler, B., von Lengerke, T., Emeny, R., Heier, M., Lacruz, M.E. and Ladwig, K.H. (2014) Obesity and Symptoms of Depression and Anxiety in Pre- and Postmenopausal Women: A Comparison of Different Obesity Indicators. Psychotherapie, Psychosomatik, Medizinische Psychologie, 64, 128-135. 